\title{
Pesticide Residues In Selected Vegetable Collected From Wet Markets Of Bangladesh
}

\author{
Md. Mehedi Hasan \\ Ph. D. Researcher, Faculty of Arts and Sciences, \\ Bangladesh University of Professionals, \\ Mirpur Cantonment, Dhaka, Bangladesh. \\ Md. Azizur Rahman \\ Professor, Department of Horticulture, \\ Bangladesh Agricultural University, Mymensingh
}

\begin{abstract}
Pesticide residues in vegetable have become a major concern associated with food safety issues. Translocation of pesticides in selected vegetable samples was determined using gas chromatography-mass spectrophotometry (GC-MS) procedures and quick, easy, cheap, effective, rugged and safe (QuEChERS) method with acetate buffering (AOAC Official Method 2007.01) was used for sample preparation. Pesticide residues above the maximum residue levels (MRLs) were found in 3 brinjal, 2 country bean and 1 tomato samples. The result revealed that country bean collected from Karwanbazar, Dhaka and Jessore sadar wet market contained $44.92 \mu \mathrm{g} / \mathrm{kg}$ and $38.65 \mu \mathrm{g} / \mathrm{kg}$ Dimethoate residue, respectively. Brinjal sample collected from Jatrabari, Dhaka, Khetlal bazar and Mithapukur bazar wet market contained $32.54 \mu \mathrm{g} / \mathrm{kg}, 25.82 \mu \mathrm{g} / \mathrm{kg}$ and $20.65 \mu \mathrm{g} / \mathrm{kg}$ Quinalphos residue respectively. Tomato sample collected from Narsingdi sadar wet market contained $8.50 \mu \mathrm{g} / \mathrm{kg}$ Quinalphos residue, which was lower than Maximum Residue Levels (10 $\mu \mathrm{g} / \mathrm{kg})$.
\end{abstract}

Keywords: Pesticides, residue analysis, vegetable, gas chromatography-mass spectrophotometry (GC-MS) and food safety.

\section{INTRODUCTION}

Vegetable are major part of diet contributing nutrients, vitamins and minerals. Vegetable grown in Bangladesh are vulnerable to be contaminated by different pesticides. Contamination of foods with toxic chemicals poses a serious threat to public health, especially in a country like Bangladesh where due to poor health literacy and the level of awareness is very low. Pesticides have been associated with a wide spectrum of human health hazards ranging from short-term impacts such as headache and nausea to chronic impacts like cancer, reproductive harm and endocrine disruption (Chowdhury et al., 2014). Quality control and assuring safety of fruits and vegetable have become one of the major challenging issues in Bangladesh. Often consumers are dissatisfied with the poor quality product mainly due to sub-standard postharvest handling of pesticides. On the other hand, the issue of food safety has been emerged as the most serious threat in the context of nutrition security and public health of the country. There are huge concerns over the use of harmful chemicals during production and postproduction stages. The main concerns related to the presence of heavy materials, chemical residues and microbial contamination. Farmers usually apply pesticides excessively, indiscriminately and irrationally as they are not aware about the risks of pesticide residues, the guidelines on dosage and timing to use or the standardized regulations in pesticide application. This is the root of residue problems of pesticide (Zhou, 2009). The present study was carried out to determine the presence of organophosphate residues in 5 vegetable crops collected from selected areas of 
Bangladesh aiming to design appropriate controlling measures for ensuring food safety and build awareness among the consumers. Besides, the study will help to measure residual effect of pesticides, assess quality and food safety of commercially grown vegetable and to make aware the farmers and consumers about the effect of pesticides on human health.

\section{METHODOLOGY \\ Study period, sample size and sample collection locations}

The study was conducted during the period September 24, 2017 to April 21, 2018. Total 30 vegetable samples (5 samples per commodity) of brinjal, tomato, green chili, cucumber and country bean collected from Karwan bazar, Jatrabari bazar, Khetlal bazar, Joypurhat, Jessore sadar bazar, Mithapukur bazar, Rangpur and Narsingdi sadar bazar. These places are well known for seasonal vegetable production.

\section{Sample testing method}

Collected samples were tested in National Food Safety Laboratory (NFSL), Institute of Public Health, Mohakhali, Dhaka. Samples were analyzed by GC-MS (GasChromatography-Mass Spectrometry) and quick, easy, cheap, effective, rugged and safe (QuEChERS) method with acetate buffering (AOAC Official Method 2007.01) was used for sample preparation.

\section{Sample collection and preservation}

Samples were collected as per protocol and with standard carrying tools. Food graded polybags for sample package and jute bags were used for carrying packaged sample. Three samples (500 gm each) of same vegetable from three different sellers collected in same wet market. Then three samples mixed thoroughly and collected 500 gm from the mixed samples for laboratory testing. The samples kept in food graded polybags with identifying mark. Following the same procedure, total 25 samples collected from 5 different wet markets and taken to NSFL. After reaching to NSFL, the samples were checked, provided laboratory code marks and received. The samples were stored at appropriate temperature $\left(2-8^{0} \mathrm{C}\right)$ until analysis completed. 
Table 1: Information of collected vegetable samples

\begin{tabular}{|c|c|c|c|}
\hline $\begin{array}{l}\text { Sl } \\
\text { no }\end{array}$ & Bazar name & Sample number & $\begin{array}{c}\text { Sample collection } \\
\text { date }\end{array}$ \\
\hline 1 & $\begin{array}{l}\text { Karwan Bazar wet market, } \\
\text { Dhaka }\end{array}$ & $\begin{array}{l}\text { BRK: Brinjal Karwanbazar } \\
\text { TOK: Tomato Karwanbazar } \\
\text { CHK: Chili Karwanbazar } \\
\text { CUK: Cucumber Karwanbazar } \\
\text { CBK: Country Bean Karwanbazar }\end{array}$ & 24 September 2017 \\
\hline 2 & $\begin{array}{l}\text { Jatrabari wet market, } \\
\text { Dhaka }\end{array}$ & $\begin{array}{l}\text { BRJ: Brinjal Jatrabari } \\
\text { TOJ: Tomato Jatrabari } \\
\text { CHJ: Chili Jatrabari } \\
\text { CUJ: Cucumber Jatrabari } \\
\text { CBJ: Country Bean Jatrabari }\end{array}$ & 3 October 2017 \\
\hline 3 & $\begin{array}{l}\text { Khetlal bazar wet market, } \\
\text { Joypurhat }\end{array}$ & $\begin{array}{l}\text { BRJOY: Brinjal Joypurhat } \\
\text { TOJOY: Tomato Joypurhat } \\
\text { CHJOY: Chilli Jpypurhat } \\
\text { CUJOY: Cucumber Joypurhat } \\
\text { CBJOY: Country bean Joypurhat }\end{array}$ & April 21, 2018 \\
\hline 4 & Jessore sadar wet market & $\begin{array}{l}\text { BRJSR: Brinjal Jessore } \\
\text { TOJSR: Tomato Jessore } \\
\text { CHJSR: Chili Jessore } \\
\text { CUJSR: Cucumber Jessore } \\
\text { CBJSR: Cucumber Jessore }\end{array}$ & April 21, 2018 \\
\hline 5 & $\begin{array}{l}\text { Narsingdi sadar wet } \\
\text { market }\end{array}$ & $\begin{array}{l}\text { BRN: Brinjal Narsingdi } \\
\text { TON: Tomato Narsingdi } \\
\text { CHN: Chili Narsingdi } \\
\text { CUN: Cucumber Narsingdi } \\
\text { CBN: Country Bean Narsingdi }\end{array}$ & April 20, 2018 \\
\hline 6 & $\begin{array}{l}\text { Mithapukur bazar wet } \\
\text { market, Rangpur }\end{array}$ & $\begin{array}{l}\text { BRR: Brinjal Rangpur } \\
\text { TOR: Tomato Rangpur } \\
\text { CHR: Chili Rangpur } \\
\text { CUR: Cucumber Rangpur } \\
\text { CBR: Country Bean Rangpur }\end{array}$ & April 21, 2018 \\
\hline
\end{tabular}

\section{Sample preparation and testing}

For sample preparation, a quick, easy, cheap, effective, rugged and safe (QuEChERS) method with acetate buffering (AOAC Official Method 2007.01) was used. After homogenization with a house-hold mill, $15 \mathrm{gm}$ of the homogenized sample was weighed into a $50 \mathrm{~mL}$ Falcon tube and $100 \mathrm{ml}$ of $50 \mathrm{mg} / \mathrm{ml}$ triphenyl phosphate (TPP) surrogate standard solution in acetonitrile was added followed by $15 \mathrm{~mL}$ of acetonitrile containing 1\% acetic acid. Then, 6 gm $\mathrm{MgSO}_{4}$ and $2.5 \mathrm{~g}$ sodium acetate trihydrate were added and the sample was mixed well by vortex. The sample was then centrifuged at $5000 \mathrm{rpm}$ for 5 minutes. $5 \mathrm{~mL}$ of the supernatant were transferred in an eppendrop with $750 \mathrm{mg} \mathrm{MgSO}_{4}$ and $250 \mathrm{mg}$ PSA. The extract was shaken using a vortex mixture and centrifuged at $10000 \mathrm{rpm}$ for 5 minutes. Approximately $3 \mathrm{~mL}$ of the supernatant were filtered through a $0.45 \mathrm{~mm}$ filter and $800 \mathrm{~mL}$ portions were transferred to autosampler vials. The extracts were evaporated to dryness under a stream of argon and reconstituted in $800 \mathrm{~mL}$ acetonitrile/water (20/80, v/v) for the GC-MS analysis. 


\section{Homogenize the commodity to generate a uniform sample}

\section{Weigh $15 \mathrm{gm}$ of the homogenized sample into a $50 \mathrm{ml}$ Falcon tube}

\section{Add acetonitrile, $\mathrm{MgSO}_{4}$ and sodium acetate trihydrate. Mix well by vortex mixture}

\section{Centrifuge the sample at 5000 rpm for 5 minutes.}

Transfer the supernatant in an eppendrop with $\mathrm{MgSO}_{4}$, PSA and Charcoal

\section{Shake vigorously by vortex mixture}

\section{Centrifuge at $10000 \mathrm{rpm}$ for 5 minutes}

\section{Vial and inject for GC-MS analysis}

Figure 1: Flowchart showing the steps of sample preparation of QuEChERS method

\section{GasChromatography-Mass Spectrometry (GC-MS)}

Chromatographic instrumentation and quantification were carried out by Gas chromatography-mass spectrometry (ModelGC450, Varian Inc., The Netherlands) detector equipped with split/ splitless injector with electronic pressure control. A fused silica CP-Sil 8 CB-LB/MS capillary column (30 $\mathrm{m} \times 0.25 \mathrm{~mm}$ i.d.) was used in combination with the following oven temperature program: initial temperature $50^{\circ} \mathrm{C}$, held for 2 minutes, $20^{0} \mathrm{C}$ minute ${ }^{-1} \mathrm{rpm}$ to $160^{\circ} \mathrm{C}$ held for 2 minutes, followed by $3^{0} \mathrm{C}$ minute ${ }^{-1}$ to $300^{\circ} \mathrm{C}$ held for 1 minute. The carrier gas (helium, 99.999\%) flow rate was set to a constant head pressure of $200 \mathrm{kPa}$ at flow rate of $1 \mathrm{~mL}$ minute ${ }^{-1}$. The mass spectrometer was operated in electron ionization mode with a transfer line temperature of $280^{\circ} \mathrm{C}$, manifold temperature $40^{\circ} \mathrm{C}$, trap temperature $200^{\circ} \mathrm{C}$, filament number 2 , ion source $230^{\circ} \mathrm{C}$ and selected ion monitoring (SIM) mode. The ion energy for electron impact (EI) was kept at $70 \mathrm{eV}$. MS Workstation version 6.9.1 was used for data acquisition. For positive identification, both retention time (Rt) and the presence of three fragment ions were considered. 


\section{RESULTS AND DISCUSSION}

Table 2: Analysis of vegetable samples for determining pesticides residue Analysis of vegetable samples of Karwanbazar wet market for pesticides residue

\begin{tabular}{|c|c|c|c|c|c|c|c|c|c|}
\hline \multirow{2}{*}{$\begin{array}{c}\text { Vegetable } \\
\text { name }\end{array}$} & \multirow{2}{*}{$\begin{array}{l}\text { Collected } \\
\text { Location }\end{array}$} & \multicolumn{8}{|c|}{ Quantity of detected residue $(\mu \mathrm{g} / \mathrm{kg})$} \\
\hline & & $\begin{array}{l}\text { Dimeth } \\
\text { oate }\end{array}$ & $\begin{array}{l}\text { Ethopro } \\
\text { phos }\end{array}$ & $\begin{array}{l}\text { Diazini } \\
\text { on }\end{array}$ & $\begin{array}{l}\text { Malathi } \\
\text { on }\end{array}$ & $\begin{array}{l}\text { Fent } \\
\text { hion }\end{array}$ & $\begin{array}{l}\text { Cloropyri } \\
\text { phos }\end{array}$ & $\begin{array}{l}\text { Quinalph } \\
\text { os }\end{array}$ & $\begin{array}{l}\text { Cypermet } \\
\text { hrin }\end{array}$ \\
\hline Brinjal & \multirow{5}{*}{$\begin{array}{l}\text { Karwanbaza } \\
\text { r wet } \\
\text { market }\end{array}$} & ND & $\mathrm{ND}$ & ND & ND & ND & ND & ND & ND \\
\hline Tomato & & ND & ND & ND & ND & ND & ND & ND & ND \\
\hline Green chili & & ND & ND & ND & ND & ND & ND & ND & ND \\
\hline Cucumber & & ND & ND & ND & ND & ND & ND & ND & ND \\
\hline $\begin{array}{l}\text { Country } \\
\text { bean }\end{array}$ & & $\begin{array}{c}44.92 \pm \\
3.5\end{array}$ & ND & ND & ND & ND & ND & ND & ND \\
\hline
\end{tabular}

Analysis of vegetable samples of Jatrabari market for pesticides residue

\begin{tabular}{|c|c|c|c|c|c|c|c|c|c|}
\hline Brinjal & \multirow{5}{*}{$\begin{array}{l}\text { Jatrabari } \\
\text { wet market }\end{array}$} & ND & ND & ND & ND & ND & ND & $\begin{array}{c}32.54 \pm \\
2.85 \\
\end{array}$ & ND \\
\hline Tomato & & ND & ND & ND & ND & ND & ND & ND & ND \\
\hline Green chili & & $\mathrm{ND}$ & ND & ND & ND & ND & ND & ND & ND \\
\hline Cucumber & & $\mathrm{ND}$ & $\mathrm{ND}$ & ND & ND & ND & ND & ND & ND \\
\hline $\begin{array}{l}\text { Country } \\
\text { bean }\end{array}$ & & ND & ND & ND & ND & ND & ND & ND & ND \\
\hline
\end{tabular}

Analysis of vegetable samples of Khetlal bazar wet market, Joypurhat for pesticides residue

\begin{tabular}{|c|c|c|c|c|c|c|c|c|c|}
\hline Brinjal & \multirow{5}{*}{$\begin{array}{l}\text { Khetlal } \\
\text { bazar wet } \\
\text { market, } \\
\text { Joypurhat }\end{array}$} & ND & ND & ND & ND & ND & ND & $\begin{array}{c}25.82 \pm \\
5.65\end{array}$ & ND \\
\hline Tomato & & ND & ND & ND & ND & ND & ND & ND & ND \\
\hline Green chili & & ND & ND & ND & ND & ND & ND & ND & ND \\
\hline Cucumber & & ND & ND & ND & ND & ND & ND & ND & ND \\
\hline $\begin{array}{l}\text { Country } \\
\text { bean }\end{array}$ & & ND & ND & ND & ND & ND & ND & ND & ND \\
\hline
\end{tabular}

Analysis of vegetable samples of Jessore sadar wet market for pesticides residue

\begin{tabular}{|c|c|c|c|c|c|c|c|}
\hline Brinjal & \multirow{5}{*}{$\begin{array}{l}\text { Jessore } \\
\text { sadar wet } \\
\text { market }\end{array}$} & ND & ND & ND & ND & ND & $\mathrm{N}$ \\
\hline Tomato & & ND & ND & ND & ND & ND & $\mathrm{N}$ \\
\hline Green chili & & ND & ND & ND & ND & ND & $\mathrm{N}$ \\
\hline Cucumber & & ND & ND & ND & ND & ND & $\mathrm{N}$ \\
\hline $\begin{array}{l}\text { Country } \\
\text { bean }\end{array}$ & & $\begin{array}{c}38.65 \pm \\
3.25\end{array}$ & ND & ND & ND & ND & $\mathrm{N}$ \\
\hline
\end{tabular}

\begin{tabular}{|c|c|c|c|c|c|c|c|c|c|}
\hline \multicolumn{10}{|c|}{ Analysis of vegetable samples of Narsingdi sadar wet market for pesticides residue } \\
\hline Brinjal & \multirow{5}{*}{$\begin{array}{l}\text { Narsingdi } \\
\text { sadar wet } \\
\text { market }\end{array}$} & ND & ND & ND & ND & ND & ND & ND & ND \\
\hline Tomato & & ND & ND & ND & ND & ND & ND & $8.50 \pm 1.95$ & ND \\
\hline Green chili & & ND & ND & ND & ND & ND & ND & ND & ND \\
\hline Cucumber & & ND & ND & ND & ND & ND & ND & ND & ND \\
\hline $\begin{array}{l}\text { Country } \\
\text { bean }\end{array}$ & & ND & ND & ND & ND & ND & ND & ND & $\mathrm{ND}$ \\
\hline
\end{tabular}

Analysis of vegetable samples of Mithapukur bazar, Rangpur wet market for pesticides residue

\begin{tabular}{|c|c|c|c|c|c|c|c|c|c|}
\hline Brinjal & \multirow{5}{*}{$\begin{array}{l}\text { Mithapukur } \\
\text { bazar wet } \\
\text { market, } \\
\text { Rangpur }\end{array}$} & ND & ND & ND & ND & ND & ND & $\begin{array}{c}20.65 \pm \\
4.35\end{array}$ & ND \\
\hline Tomato & & ND & ND & ND & ND & ND & ND & ND & ND \\
\hline Green chili & & ND & ND & ND & ND & ND & ND & ND & ND \\
\hline Cucumber & & ND & ND & ND & ND & ND & ND & ND & ND \\
\hline $\begin{array}{l}\text { Country } \\
\text { bean }\end{array}$ & & ND & ND & ND & ND & ND & ND & ND & ND \\
\hline
\end{tabular}

$\mathrm{ND}=$ Not Detected 


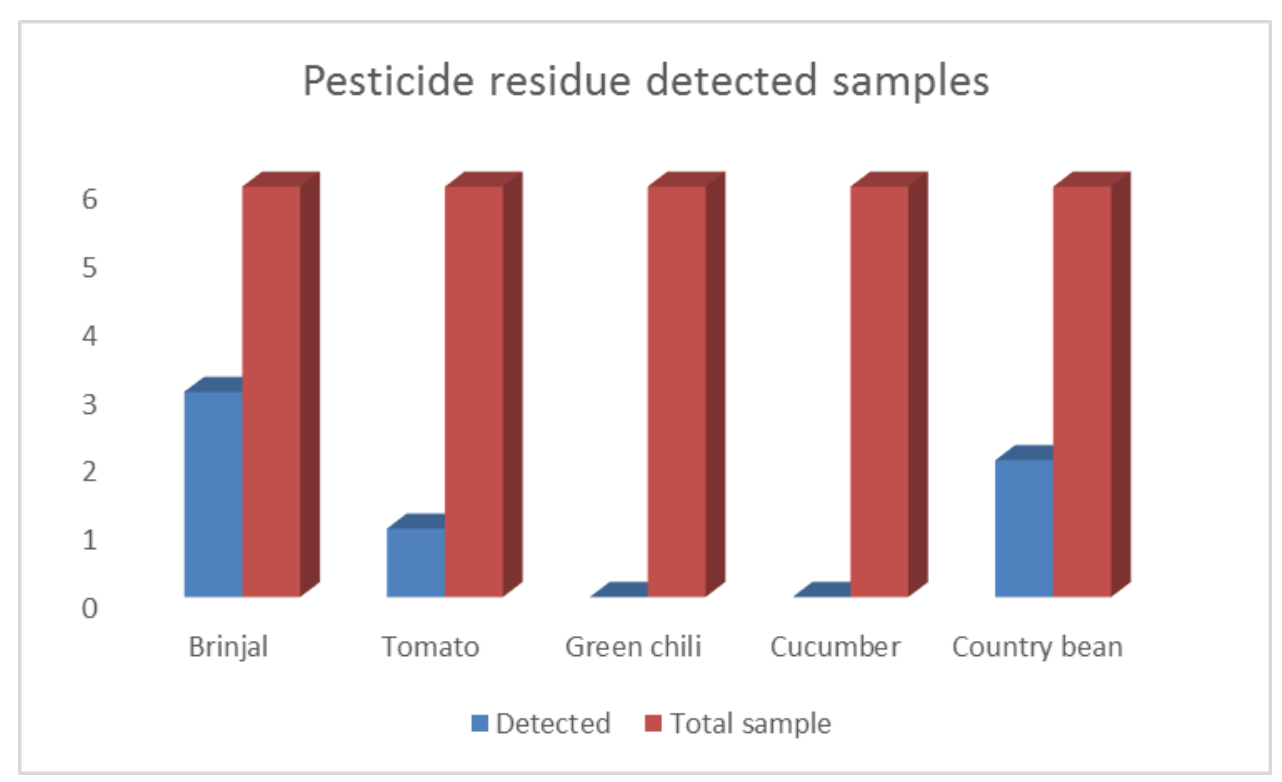

Figure 2: Pesticide residue detected in vegetable samples

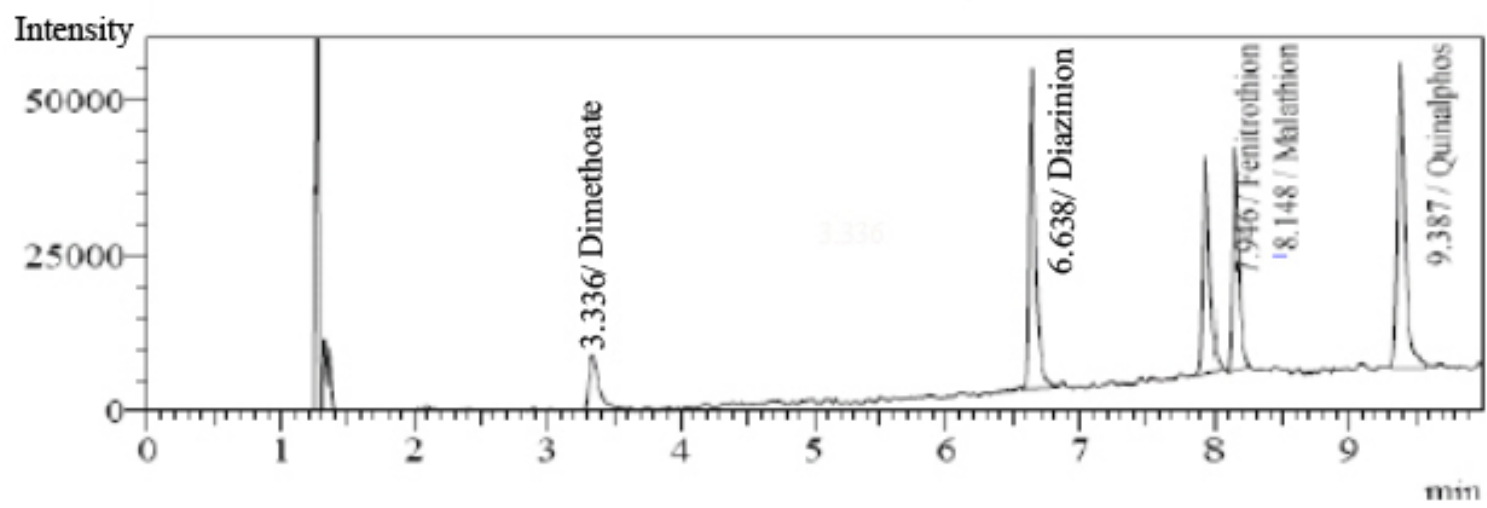

Figure 3: Chromatogram of standard organophosphorus pesticides

Total 30 samples of brinjal, tomato, green chili, cucumber and country bean were analyzed in the laboratory. Pesticide residues detected in 3 brinjal samples, 2 country bean samples and 1 tomato sample (figure 2). The result showed (table 2) that country bean collected from Karwanbazar, Dhaka wet market contained $44.92 \mu \mathrm{g} / \mathrm{kg}$ Dimethoate residue, which is higher than Maximum Residue Levels $(20 \mu \mathrm{g} / \mathrm{kg})$. Other samples of Karwanbazar, market did not contain any residue of pesticides. Brinjal sample collected from Jatrabari, Dhaka wet market contained $32.54 \mu \mathrm{g} / \mathrm{kg}$ Quinalphos residue, which is higher than Maximum Residue Levels (10 $\mu \mathrm{g} / \mathrm{kg}$ ). Other samples of Jatrabari market did not contain any residue of pesticides. Brinjal sample of Khetlal bazar, Joypurhat wet market, Joypurhat was positive to Quinalphos and the concentration was $25.82 \mu \mathrm{g} / \mathrm{kg}$, which is higher than Maximum Residue Levels $(10 \mu \mathrm{g} / \mathrm{kg})$. Other samples of Khetlal bazar did not contain any residue of pesticides.

Country bean sample of Jessore sadar wet market contained $38.65 \mu \mathrm{g} / \mathrm{kg}$ Dimethoate, which is higher than Maximum Residue Levels $(20 \mu \mathrm{g} / \mathrm{kg})$. Tomato, brinjal, cucumber and green chili of Jessore sadar wet market did not contain any residue of pesticides. El-Saeid and Selim (2013) detected residues of organophosphorus, organochlorine, pyrethroid and carbamate from market vegetables (viz., beans, eggplant, cauliflower, tomato, pepper, carrot, cucumber, squash, potato, onions and okra) which showed above the MRL in 15.89\% of the total tested samples. Rahman et al. (2014) found 26\% vegetables (viz., brinjal, hyachinth bean, cabbage, cauliflower 
and red amaranth) samples from five major vegetables growing regions (Bogra, Jessore, Norsingdi, Jamalpur and Rajshahi of Bangladesh) were contaminated with dimethoate, chlorpyriphos and quinalphos residues, of which $24 \%$ of the contaminated samples contained residue above MRL. The mean concentration of carbaryl residue $0.10 \mathrm{mg} / \mathrm{kg}$ in tomato and $0.09 \mathrm{mg} / \mathrm{kg}$ found in brinjal in Al-Qassim region of Saudi Arabia (Osman et al., 2011). Tomato sample collected from Narsingdi sadar wet market contained $8.50 \mu \mathrm{g} / \mathrm{kg}$ Quinalphos residue, which is lower than Maximum Residue Levels $(10 \mu \mathrm{g} / \mathrm{kg})$. No pesticide residues detected in other samples of Narsingdi sadar wet market. Brinjal sample of Mithapukur bazar, Rangpur wet market contained $0.65 \mu \mathrm{g} / \mathrm{kg}$ Quinalphos residue, which is higher than Maximum Residue Levels $(10 \mu \mathrm{g} / \mathrm{kg})$. These results are in accordance with those of Yu et al., 2016 who monitored organophosphorus pesticides (OPs) in leafy vegetables in Changchun, China. Tomato, cucumber, green chili and country bean of Mithapukur bazar were negative to pesticide residues. Bempah et al., 2008 analyzed in laboratory and found 0.007-0.019 $\mathrm{mg} / \mathrm{kg}$ dimethoate residue in Ghanaian tomatoes and $0.001-0.002 \mathrm{mg} / \mathrm{kg}$ in Indian eggplants (Kumari 2008). Osman et al., 2011 recorded the mean concentration of carbaryl residue as $0.10 \mathrm{mg} / \mathrm{kg}$ in tomato and $0.09 \mathrm{mg} / \mathrm{kg}$ in brinjal in Al-Qassim region of Saudi Arabia. Carbaryl residue was detected in tomato sample as $1.52 \mathrm{mg} / \mathrm{kg}$. Parent pesticides may be converted to their metabolite and hence, might remain below detection limit, though some previous studies have recorded carbamate residues in different vegetables in different region of the world (Latif et. al., 2011). Several factors er application methods may contribute to the high occurrence of pesticide residues detected in the vegetable samples from the wet markets. Bangladesh normally has an unplanned control mechanism, and rampant pesticide overdosing is practiced in field level to increase crop productivity (Rahman and Alam, 2007). Moreover, the majority of farmers lack sufficient perception and knowledge about the nature of chemical pesticides and their effects on health by consuming pesticides residues. Therefore, consumers may unknowingly consume vegetables and fruits containing uncontrolled levels of pesticide residues that ultimately leads to severe health problems (Chowdhury et al., 2012).

Exposure to pesticides through contaminated food leads to a spectrum of adverse health effects that depend on the nature of the pesticide and on the amount and duration of exposure (Gupta 2014). Symptoms of exposure to organophosphates such as Dimethoate, Ethoprophos, Diazinion, Malathion, Quinalphos, Cypermethrin, parathion, and phosphamidon cause different types of health problems like miosis, urination, diarrhea, diaphoresis, lacrimation, excitation, and salivation (Moore 2009). Psychological and behavioral effects of organophosphorus pesticide like anxiety, depression, coma and convulsions are acute exposure, while chronic exposure of pesticide residues leads to cognitive and emotional deficits. As organophosphates act directly on the nervous system, severe organophosphate exposure is clinically manifested by marked miosis and loss of the pupillary light reflex, fasciculations, flaccid paralysis, pulmonary rales, respiratory distress, and cyanosis with less than $10 \%$ of the normal value of serum cholinesterase (Kumar et. al., 2010). Exposure to carbofuran leads to overstimulation of the nervous system due to direct inhibition of acetylcholinesterase. Symptoms of carbofuran overexposure in humans include headache, weakness, abdominal cramping, nausea, blurred vision, convulsions, tremor, and coma (Tenenbaum 2008).

Pesticide residues in food and crops are a direct result of the application of pesticides to crops growing in the field, and to a lesser extent from pesticide residues remaining in the soil (Puri, 2014). Besides, due to lack of awareness and proper knowledge of the farmers, the misuse of pesticides has become a serious problem in agricultural production (Abhilash \& Singh, 2009). Hence, immediate interventions are needed to stop any malpractice during production and marketing of vegetable. Consumption of good quality, nutritious and safe vegetables can only be assured if quality and safety can be ensured at the production and postproduction stages 
(Ferdousi and Rahman, 2016). In Bangladesh, the use of toxic pesticides is increasing alarmingly and it is found that pesticides use increased by 328 percent during the last 10 years, posing a serious hazards on human health due to its long-term residual effect (BARI 2010). The problem becomes severe when the indiscriminate use of pesticides by farmers is made worse due to illiteracy and low levels of awareness of the hazardous effect of pesticides to human health (Chowdhury et. al., 2012).

\section{CONCLUSION}

Based on the result of the analysis of selected vegetable, it can be concluded that farmers are applying pesticides excessively, indiscriminately and irrationally as they are not aware about the risks of pesticide residues, the guidelines on dosage and timing to use or the standardized regulations in pesticide application. Due to lack of awareness and proper knowledge of the farmers, the misuse of pesticides has become a serious problem in agricultural production. From the study result, it is revealed that pesticide residues in brinjal, and country bean samples were higher than Maximum Residue Levels (MRLs). Long term accumulation of pesticides residues in human body via dietary intake of vegetable and other food commodities is an alarming problem. The impact of pesticide residues can be minimized by preventive measures such as rational use of pesticides, washing and proper processing of food products, practicing organic farming, use of natural pesticides and bio-pesticides, and strict implementation and amendment of pesticide-related laws. The adoption of effective legislation for properly regulating pesticide use and increasing awareness and technical know-how in the farming community should be incorporated. The study results may upgrade the knowledge of consumers, public health experts and policy makers regarding pesticide residues in vegetable and can help for setting guidelines and monitoring pesticide residues to save human health.

\section{References}

Abhilash, P.C. and Singh, N. (2009). Pesticides use and application: An Indian scenario. Journal of Hazardous Materials, 165 (1-3), pp.1-12.

Bangladesh Rice Research Institute (BRRI) (2010). Survey Report on Pesticides, Gazipur: BRRI.

BBS (2014). Statistical Yearbook of Bangladesh, Bangladesh Bureau of Statistics, Planning division, Ministry of Planning, Government of the People's Republic of Bangladesh, Dhaka.

Bempah, C. K. J., Asomaning, D. A., Ansong, J., Boateng, and Asabere, S. B. (2012). Contamination levels of selected organochlorine and organophosphorou pesticides in Ghanaian fruits and vegetables. Emirates Journal of Food and Agriculture, 24(4), pp. 293-301.

Chowdhury, A. Z., Jahan, S. A. and Islam, M. N. (2012). Occurrence of organophosphorus and carbamate pesticide residues in surface water samples from the Rangpur district of Bangladesh. Bulletin of Environmental Contamination and Toxicology, 89(1), pp. 202-207.

Chowdhury, A.Z., Hasan, M., Karim, N., Fakhruddin, A.N.M., Hossain, S. and Chowdhury, A.K.M. (2014). Contamination and health risk assessment of pesticide residues in vegetables from agricultural fields of Gazipur District, Bangladesh. Am-Euras. J. Agric and Environ. Sci., 14(5), pp. 421-427.

Chowdhury, M.A.Z., Banik, S., Uddin, B., Moniruzzaman, M., Karim, N. and Gan, S.H. (2012). Organophosphorus and carbamaten pesticide residues detected in water samples collected from paddy and vegetable fields of the Savar and Dhamrai Upazilas in Bangladesh. International Journal of Environmental Research and Public Health, 9(9), pp. 3318-3329.

El-Saeid, M. H. And Selim, M. T. (2013). Multiresidue analysis of 86 pesticides using Gas Chromatography Mass Spectrometry: II-non leafy vegetables. Journal of Chemistry, pp. 1-10.

Ferdousi, S. and Rahman, M.M. (2016). Survey Report of Horticultural Products and Other Food Commodities for Chemical Contamination. National Food Safety Laboratory, Institute of Public Health, Mohakhali, Dhaka-1212.

Gupta, R. C. (2014). “Carbofuran toxicity,” Journal of Toxicology and Environmental Health, 43(4), pp. 383-418.

Kumar, S.V. M., Fareedullah, Y., Sudhakar, B., Venkateswarlu, and Kumar, E. A. (2010). “Current review on organophosphorus poisoning," Archives of Applied Science Research, 2(4), pp. 199-215. 
Kumari, B. (2008). Effects of household processing on reduction of pesticide residues in vegetables. ARPN Journal of Agricultural and Biological Science, 3(4), pp. 46-48.

Latif, Y., Sherazi, S.T.H. and Bhanger, M.I. (2011). Assessment of pesticide residues in commonly used vegetables in Hyderabad, Pakistan. Ecotoxicol. Environ. Safety, (74), pp. 2299-2303.

Moore, P. C. F. (2009). Children and Pollution: Why Scientists Disagree, Oxford University Press, Oxford, UK.

Osman, K.A., Al-Humaid, A.I., Al-Rehiayani, S.M. and Al-Redhaiman, K.N. (2011). Estimated daily intake of pesticide residues exposure by vegetables grown in greenhouses in Al-Qassim region, Saudi Arabia, pp. 947-953.

Puri, P. (2014). Food safety assurance through regulation of agricultural pesticide use in India: perspectives and prospects. Journal of Life Science, 3(2), pp. 123-127.

Rahman, M.A., Ahmed, M. S., Akon, M. W. and Afroza, B. (2014). Pesticide residue analysis in vegetables collected from different regions of Bangladesh. Annual Report, Entomology Division, Bangladesh Agricultural Research Institute, Joybebpur, Gazipur, Bangladesh, pp. 257-263.

Rahman M. and Alam, M. (2007). Risk assessment of pesticides used in Bangladesh. Journal of Civil Engineering, 25(1), pp. 97-106.

Tenenbaum, D. (2008) “Pesticides: carbofuran under review,” Environmental Health Perspectives, 116(10), pp.425-30.

Yu, R., Liu, Q., Liu, J., Wang, Q. and Wang, Y. (2016). Concentrations of organophosphorus pesticides in fresh vegetables and related human health risk assessment in Changchun, Northeast China. Food Control, (60), pp. 353360 .

Zhou, J. and Jin, A. (2009). Safety of vegetable and the use of pesticides by farmers' in China: Evidence from Zhejiang province. Food Control, 20(2), pp. 419-422. 